\title{
Isolation and Properties of a New Hydrogen Bacterium Related to Pseudomonas saccharophila
}

\author{
By NORBERTO J. PALLERONI \\ Chemical Research Department, Hoffmann-La Roche Inc., Nutley, New Jersey 07110, U.S.A.
}

(Received 10 July 1979)

\begin{abstract}
A strain of hydrogen bacteria, phenotypically resembling Pseudomonas saccharophila, was extensively characterized. On the basis of a comparative study of the phenotypic properties of both organisms, and of DNA-DNA reannealing experiments with $P$. saccharophila and other species of the genus, it is concluded that the new strain is probably a member of a new species related to $P$. saccharophila. It is suggested that formal proposal of the new species be postponed until a larger collection of organisms of this group becomes available.
\end{abstract}

\section{INTRODUCTION}

Non-pigmented hydrogen pseudomonads have been isolated from nature far less frequently than the yellow-pigmented members of this physiological group of Pseudomonas species. Of the three species of non-pigmented hydrogen pseudomonads described in Bergey's Manual (Doudoroff \& Palleroni, 1974), $P$. facilis and P. saccharophila are currently accepted members of the genus, while Aragno \& Schlegel (1977) have suggested that $P$. ruhlandii should be assigned to the genus Alcaligenes. Pseudomonas facilis has been isolated on two occasions (Schatz \& Bovell, 1952; Kluyver \& Manten, 1942; Davis, 1967) and at present there is one known strain of $P$. saccharophila, which was isolated by Doudoroff (1940).

The single strain of $P$. saccharophila has been extensively investigated for its carbohydrate metabolism (Palleroni, 1956; 1978). Several attempts by Doudoroff and colleagues (unpublished work) to isolate other strains of the species from soil and water samples failed, but in 1971 a non-pigmented hydrogen pseudomonad able to grow heterotrophically at the expense of starch was isolated from an enrichment in a class experiment of the Department of Bacteriology of the University of California at Berkeley, U.S.A. This organism appeared to show a close resemblance to $P$. saccharophila, and the two strains were found to have identical DNA base composition (M. Mandel, personal communication). This paper reports the phenotypic properties of the new organism and its DNA homology relative to the single strain of $P$. saccharophila. On the basis of the results, it is suggested that the new strain represents a new species of the genus Pseudomonas.

\section{METHODS}

Strains. Pseudomonas saccharophila ATCC 15946, P. facilis ATCC 11228, ATCC 17695 and Davis 458 (DSM 620) and P. solanacearum NCPPB 325 and NCPPB 1029 were obtained from the bacterial collection of the Department of Bacteriology of the University of California at Berkeley, U.S.A. The new strain was isolated by Ms Elaine Paladini and Ms Barbara Bacigalupi, two bacteriology students working under the direct supervision of Dr John Waterbury, who kindly made the strain available to me.

Phenotypic characterization. The methods described by Stanier et al. (1966), Davis et al. (1970) and Palleroni \& Doudoroff (1972) were used. Gelatin hydrolysis was tested by a modification of the method 
described by Skerman (1967). Plates containing $10 \mathrm{ml}$ mineral agar (Palleroni \& Doudoroff, 1972) were overlaid with $10 \mathrm{ml}$ mineral agar containing $1 \mathrm{ml}$ of a neutralized gelatin solution $(25 \%, \mathrm{w} / \mathrm{v})$ in mineral medium. Cultures were patched on to the surface of this medium and, after $4 \mathrm{~d}$ incubation at $30^{\circ} \mathrm{C}$, gelatin hydrolysis was detected by flooding the plates with the $\mathrm{HgCl}_{2} / \mathrm{HCl}$ solution described by Skerman (1967). Gelatin hydrolysis was also tested in the same medium containing $0.25 \%(\mathrm{w} / \mathrm{v})$ sucrose.

Nutritional properties. Liquid mineral medium (Palleroni \& Doudoroff, 1972) containing single carbon sources (see Results) at a final concentration of $0.1 \%(\mathrm{w} / \mathrm{v})$ was used. Carbohydrates were also tested at $0.25 \%(\mathrm{w} / \mathrm{v})$, and fatty acids and aromatic compounds at 0.025 and $0.05 \%(\mathrm{w} / \mathrm{v})$. Cultures grown autotrophically under an atmosphere of $\mathrm{H}_{2} / \mathrm{O}_{2} / \mathrm{CO}_{2} / \mathrm{N}_{2}(50: 8: 5: 37$, by vol.) were used for inoculation. Incubation was at $30^{\circ} \mathrm{C}$ in a water bath with fast rotatory shaking. After several days incubation, growth was judged visually and recorded as + (good growth), - (no growth) or \pm (limited growth).

Isolation of mutants. Spontaneous mutants able to utilize monosaccharides for growth were obtained by heavy streaking on plates of mineral medium (Palleroni \& Doudoroff, 1972) containing glucose, fructose or mannose $(0.25 \%, w / v)$ as sole carbon source, and picking the larger colonies formed after 7 to $10 \mathrm{~d}$ incubation at $30^{\circ} \mathrm{C}$.

Enzyme assays. Sucrose phosphorylase (EC 2.4.1.7) was assayed in cell-free preparations by the method of Doudoroff (1955) and glucose-6-phosphate dehydrogenase (EC 1.1.1.49) by that of DeMoss (1955). 6-Phosphogluconate dehydratase (EC 4.2.1.12) and 2-keto-3-deoxy-6-phosphogluconate aldolase (EC 4.1.2.14) were identified in extracts by the method of MacGee \& Doudoroff (1954) and were also tested individually as described by Meloche \& Wood (1966) and Meloche et al. (1966). Mannose isomerase (EC 5.3.1.7) was assayed by the method of Palleroni \& Doudoroff (1956).

DNA analyses. The DNA base composition was kindly determined by Dr Manley Mandel, using the CsCl buoyant density method.

The DNA extraction and DNA reannealing experiments were done by the methods described by Ballard et al. (1970). Nitrocellulose filters with an average of $42 \mu \mathrm{g}$ immobilized DNA were incubated for $12 \mathrm{~h}$ at $73^{\circ} \mathrm{C}$ in the reaction mixture containing radioactive homologous DNA and non-radioactive competitor DNA. The stability of the duplexes formed in the hybridization was examined on filters which had been exposed to either homologous or heterologous radioactive DNA in the absence of competitor DNA. After hybridization, these filters were immersed individually in $1 \mathrm{ml} 0.5 \times \mathrm{SSC}$ (SSC buffer is $0.15 \mathrm{M}-\mathrm{NaCl}, 0.015$ M-trisodium citrate, $\mathrm{pH} 8.0$ ) in tubes placed in a well-regulated water bath and heated at a given temperature for $5 \mathrm{~min}$. The liquid was then pipetted off, $1 \mathrm{ml}$ pre-heated $0 \cdot 5 \times \mathrm{SSC}$ buffer was added to each tube and the temperature of the bath was raised by $5{ }^{\circ} \mathrm{C}$. The temperature range of these successive treatments was from 50 to $100^{\circ} \mathrm{C}$, at $5{ }^{\circ} \mathrm{C}$ intervals. During the heating the tubes were shaken gently in the water bath. Portions of the various liquid samples were counted in a scintillation counter.

The degree of binding between the DNA of $P$. saccharophila and that of the new strain was also estimated from reannealing rates, measured by a minor modification of the spectrophotometric method of De Ley et al. (1970). A Gilford thermoprogrammer model 2527 attached to a Gilford spectrophotometer model 250, and a cuvette holder with all-quartz microcuvettes, were used. Melting profiles at $260 \mathrm{~nm}$ of each of the DNA samples and of their equimolar mixture in $0 \cdot 1 \times \mathrm{SSC}$ were recorded. When denaturation was complete, the salt concentration in the microcuvettes was increased to $2 \times$ SSC by addition of hot $20 \times$ SSC, the temperature was quickly lowered to the optimal reannealing temperature, and the decrease in absorbance of each sample at $260 \mathrm{~nm}$ was plotted for about $60 \mathrm{~min}$. The degree of binding was calculated from the rates of renaturation by the formula of De Ley et al. (1970).

Electron microscopic examination. This was kindly done by Dr M. Boublik of the Roche Institute of Molecular Biology, Nutley, N.J., U.S.A. Cells grown in the mineral medium (Palleroni \& Doudoroff, 1972) with $0.25 \%(\mathrm{w} / \mathrm{v})$ sucrose at $30{ }^{\circ} \mathrm{C}$ to the middle of the exponential phase were washed with $0.05 \mathrm{M}$-phosphate buffer $\mathrm{pH} 6.8$ and pelleted by centrifugation in $1 \%(\mathrm{v} / \mathrm{v})$ glutaraldehyde in the same buffer. The pellet was resuspended in buffer and a drop of the suspension was mounted on a copper grid coated with parlodioncarbon. The specimen was washed with distilled water, blotted, air-dried, shadowed with platinum/palladium $(80: 20)$ alloy at an angle of $10^{\circ}$ and examined in a Jeol model JEM-1000B electron microscope at $80 \mathrm{kV}$ and a direct magnification of $10000 \times$.

Flagella staining. Conventional flagella staining was done by the method of Leifson (1951).

\section{RESULTS}

The main differentiating features of $P$. facilis, $P$. saccharophila and the new strain are shown in Tables 1 and 2. The detailed properties of the new strain were as follows. 


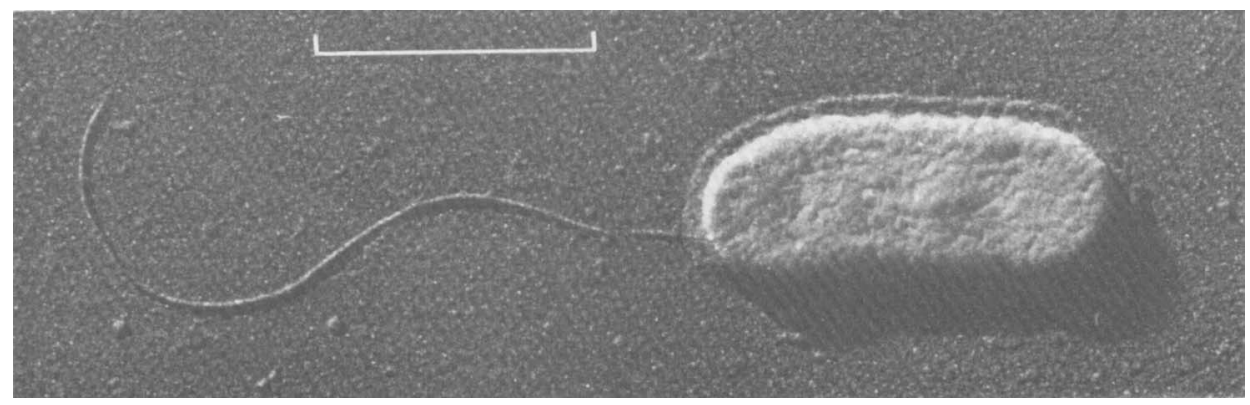

Fig. 1. Electron micrograph of a cell of the new strain shadowed with a platinum/palladium alloy. Bar marker represents $1 \mu \mathrm{m}$.

\section{Morphology}

Cells were rods 0.6 to $0.8 \mu \mathrm{m} \times 1.2$ to $2.2 \mu \mathrm{m}$ appearing singly, in pairs and, more rarely, in short chains. They were motile by means of a single polar flagellum (Fig. 1); the mode of flagellation remained essentially unchanged by growth under autotrophic or heterotrophic conditions, on solid or liquid media, at either 20 or $30^{\circ} \mathrm{C}$. Under conditions of nitrogen limitation, the cells accumulated poly- $\beta$-hydroxybutyrate.

\section{Physiological properties}

The optimum temperature for heterotrophic growth was about $35^{\circ} \mathrm{C}$. Growth was faster at $37^{\circ} \mathrm{C}$ than at $28^{\circ} \mathrm{C}$. No growth occurred at $10^{\circ} \mathrm{C}$ or at $41{ }^{\circ} \mathrm{C}$. In parallel tests, $P$. saccharophila grew very well at $30^{\circ} \mathrm{C}$, extremely poorly at $10^{\circ} \mathrm{C}$ and not at all at $37^{\circ} \mathrm{C}$.

Interestingly, no growth occurred under autotrophic conditions at $37^{\circ} \mathrm{C}$, which suggests that some enzyme(s) of the autotrophic metabolism may be temperature sensitive. This point has not been explored further.

The new strain grew well autotrophically at $30{ }^{\circ} \mathrm{C}$ in mineral medium in contact with an atmosphere of $\mathrm{H}_{2} / \mathrm{O}_{2} / \mathrm{CO}_{2} / \mathrm{N}_{2}(55: 8: 5: 32$, by vol.). Oxygen at concentrations higher than $10 \%(\mathrm{v} / \mathrm{v})$ inhibited growth.

No growth factors were needed for autotrophic or heterotrophic growth.

Eight single-colony isolates of the new strain and the strain of $P$. saccharophila were tested for heterotrophic growth at the expense of all the carbon sources listed below. Strains of $P$. facilis were only tested for growth on the substrates that, according to published data (Davis et al., 1970), appeared to be of diagnostic value.

Heterotrophic growth of the new strain occurred at the expense of the following carbon sources (poor growth is indicated by \pm ): L-arabinose (after a long lag period), galactose, sucrose, cellobiose, maltose, starch, saccharate, mucate, succinate, fumarate $( \pm)$, glutarate $( \pm)$, suberate, sebacate, L-malate, $\beta$-hydroxybutyrate, lactate, citrate, pyruvate $( \pm)$, 2-oxoglutarate $( \pm)$, ethanol, L-alanine $( \pm)$, D-alanine $( \pm)$, L-aspartate, L-asparagine $( \pm)$, L-glutamate, L-leucine, L-arginine, L-ornithine, L-proline, L-phenylalanine. Growth on D-glucose, D-fructose and D-mannose occurred late and appeared to involve mutational events.

The new strain did not grow on D-ribose, D-xylose, D-arabinose, L-fucose, D-fucose, Lrhamnose, trehalose, L-sorbose, lactose, melibiose, raffinose, gluconate, 2-oxogluconate, glucuronate, acetate, propionate, butyrate, valerate, caproate, caprylate, caprate, heptanoate, pelargonate, malonate, maleate, adipate, pimelate, D-malate, $\mathrm{D}(-)$-tartrate, $\mathrm{L}(+)$ tartrate, meso-tartrate, glycollate, glycerate, poly- $\beta$-hydroxybutyrate, aconitate, itaconate, mesaconate, 1-propanol, 1-butanol, erythritol, sorbitol, glycerol, meso-inositol, mannitol, dulcitol, adonitol, ethylene glycol, propylene glycol, 2,3-butylene glycol, L-mandelate, 
Table 1. Characters useful for the differentiation of Pseudomonas facilis, $P$. saccharophila and the new strain

\begin{tabular}{lccc}
\multicolumn{1}{c}{ Character } & P. facilis & P. saccharophila & New strain \\
GC content of the DNA (mol \%) & $62-64$ & 69 & 69 \\
Utilization at $30^{\circ} \mathrm{C}$ of: & & & \\
Sucrose & - & + & + \\
Poly- $\beta$-hydroxybutyrate & + & - & - \\
Malonate & + & - & - \\
Mannitol & + & - & - \\
D-Ribose & + & + & - \\
Citrate & - & + & + \\
Ethanol & - & - & + \\
L-Leucine & + & - & +
\end{tabular}

Table 2. Characters useful for the differentiation of Pseudomonas saccharophila and the new strain

Character

Heterotrophic growth at $37^{\circ} \mathrm{C}$

Utilization at $30^{\circ} \mathrm{C}$ of:

D-Ribose

D-Xylose

Trehalose

Melibiose

Raffinose

Saccharate

Mucate

Acetate, propionate, butyrate, valerate

Aconitate

Ethanol

Quinate

L-Leucine

L-Arginine

L-Ornithine
$P$. saccharophila New strain

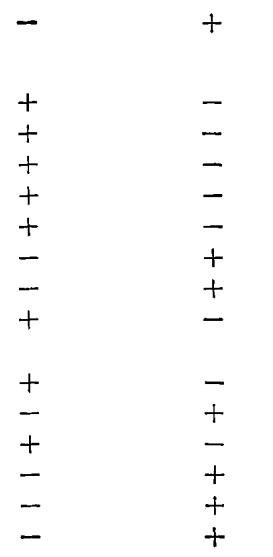

benzoate, $o$-hydroxybenzoate, $m$-hydroxybenzoate, $p$-hydroxybenzoate, gentisate, quinate, phenylacetate, phenol, glycine, $\beta$-alanine, D-aspartate, L-norleucine, L-citrulline, $\delta$-aminovalerate, L-histidine, L-tryptophan, ethanolamine, benzylamine, butylamine, $\alpha$-amylamine, betaine, sarcosine, creatine, hippurate, histamine, pantothenate, spermine, acetamide, nicotinate and trigonelline.

The nutritional properties of $P$. saccharophila and $P$. facilis were essentially identical with those reported in the literature (Davis, 1967; Davis et al., 1970).

With sucrose or galactose as sole carbon source at $0.25 \%(\mathrm{w} / \mathrm{v})$ in mineral medium, the efficiency of assimilation by the new strain was $62 \%$ and $59 \%$, respectively.

Gelatin was hydrolysed by both the new strain and by $P$. saccharophila in the two media tested. Both strains were negative in the denitrification test.

\section{Enzymic studies}

Sucrose phosphorylase activity was easily demonstrated in extracts from sucrose-grown cells. The phosphorylated product of the action of the enzyme was totally hydrolysed at $100{ }^{\circ} \mathrm{C}$ in $1 \mathrm{M}-\mathrm{HCl}$ in $7 \mathrm{~min}$, suggesting, on the one hand, that the ester was glucose 1 phosphate and, on the other, that the cells were devoid of phosphoglucomutase. In the assay of sucrose phosphorylase, a weak invertase activity was also found in the control mixtures containing no phosphate.

In extracts from sucrose-grown wild-type cells, or from glucose-grown cells of the glucose mutant strains, glucose-6-phosphate dehydrogenase activity linked to either $\mathrm{NAD}^{+}$or 


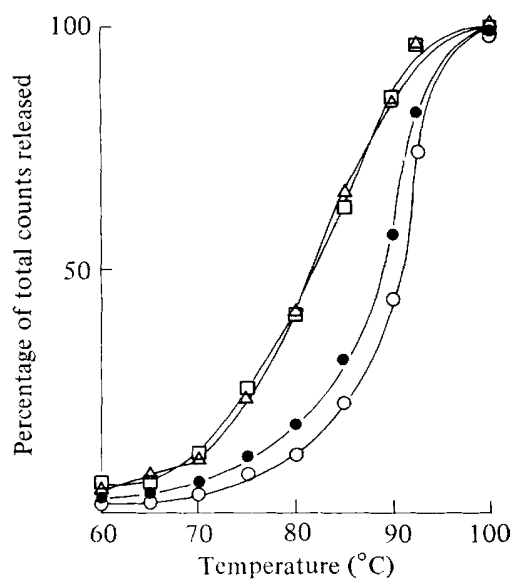

Fig. 2. Thermal denaturation profiles of DNA duplexes between $P$. saccharophila and the new strain: $P$. saccharophila DNA duplexes; $\bigcirc$, DNA duplexes from the new strain; $\triangle$, DNA from $P$. saccharophila annealed to immobilized DNA from the new strain; $\square$, DNA from the new strain annealed to immobilized $P$. saccharophila DNA.

$\mathrm{NADP}^{+}$was demonstrated. Other enzymes of the Entner-Doudoroff pathway found in these extracts were 6-phosphogluconate dehydratase and 2-keto-3-deoxy-6-phosphogluconate aldolase.

Wild-type cells were devoid of mannose isomerase, but this enzyme was present in the glucose, fructose and mannose mutants.

\section{Antibiotic sensitivity}

The new strain was more resistant than $P$. saccharophila to penicillin G (minimum inhibitory concentrations of 25 and $5 \mu \mathrm{g} \mathrm{ml}^{-1}$, respectively) (B. Prosser, personal communication). In experiments to be reported elsewhere, differences were also apparent in the composition of the penicillin-binding proteins of the cell membrane of the two organisms. The new strain possessed an inducible $\beta$-lactamase activity; this activity is constitutive in $P$. saccharophila (D. Pruess, personal communication).

\section{$D N A-D N A$ reannealing experiments}

There was $18 \%$ competition between immobilized $P$. saccharophila DNA and competitor DNA from the new strain. In a reciprocal experiment (immobilized DNA of the new strain and $P$. saccharophila DNA as competitor), $28 \%$ competition was obtained. No homology was detected between competitor DNA from any strain of $P$. facilis or $P$. solanacearum and reference DNA from either $P$. saccharophila or the new strain. The first two species were included in the experiment because they belong to the same ribosomal RNA homology group as $P$. saccharophila (Palleroni et al., 1973), although the absence of detectable DNA sequence similarity was to be expected in view of published data (Ralston et al., 1972) and the differences in base composition of the DNA samples involved in the experiment: P. facilis ATCC 17695, 63.8 mol \% GC; P. facilis DSM 620, $61.7 \mathrm{~mol} \%$ GC; P. solanacearum NCPPB 325 and 1029, 66.5 mol \% GC (Davis et al., 1970; Palleroni \& Doudoroff, 1971).

The degree of binding of DNA of the new strain to that of $P$. saccharophila, calculated from the reannealing rates, was $26 \%$.

The stability of the DNA duplexes formed between $P$. saccharophila and the new strain is indicated by the thermal denaturation profiles in Fig. 2. 


\section{DISCUSSION}

Pseudomonas saccharophila and the new strain share a group of important phenotypic characters. They are non-pigmented pseudomonads whose cells are motile by means of a polar flagellum. This property was originally reported for $P$. saccharophila by Doudoroff (1940), but at present the motility in this strain is limited to a minute fraction of the cells of any population. Both organisms are facultative autotrophs that can grow heterotrophically at the expense of starch, maltose, sucrose or cellobiose, but not with glucose, fructose or mannose, unless mutational events take place. Utilization of sucrose involves the action of sucrose phosphorylase. Mutation to the utilization of glucose, fructose or mannose correlates with the appearance of mannose isomerase activity in the cells. Both strains are negative for denitrification and are capable of gelatin hydrolysis. The finding of this last property in P. saccharophila contradicts previous reports (Doudoroff, 1940; Davis et al., 1970). The two organisms have $69 \mathrm{~mol} \% \mathrm{GC}$ in their DNA.

Pseudomonas saccharophila and the new strain differ in their optimum temperature for growth, in their sensitivity to penicillin $\mathrm{G}$ and in the utilization of various substrates. Only a low level of DNA sequence similarity can be detected between the two organisms both by the competition technique and by the spectrophotometric measurement of reannealing rates. An appreciable degree of mismatching has been detected in the hybridized fraction of the DNA. Nevertheless, the new strain is so far the only member of the genus Pseudomonas shown to share some degree of DNA homology with $P$. saccharophila.

A comment is necessary here on the properties of $P$. hydrogenovora, a species described by Kodama et al. (1975). This organism is a mesophilic hydrogen bacterium capable of using starch for heterotrophic growth, but is not clear whether it should be grouped with the so-called non-pigmented hydrogen pseudomonads. We have not examined the properties of $P$. hydrogenovora, but according to Kodama et al. (1975) the species can be easily differentiated from $P$. saccharophila phenotypically and by the base composition of its DNA.

The studies reported here suggest that the new strain may represent a new species of nonpigmented hydrogen pseudomonad, differing from $P$. saccharophila and $P$. facilis, the other two known non-pigmented hydrogenomonads, by the group of phenotypic properties presented in Table 1. Of these last two species, the new strain is more closely related to $P$. saccharophila, even though the results of DNA-DNA reannealing experiments suggest considerable divergence in DNA sequence similarity. Characters useful for differentiating between $P$. saccharophila and the new strain are presented in Table 2.

On the basis of the extensive phenotypic characterization of both $P$. saccharophila and the new strain, it is tempting to propose a new species to accommodate the latter. However, for the moment it seems unwise to do so until more strains of the ' $P$. saccharophila' group are isolated from nature. A larger collection will be the basis of a more precise circumscription of the two species and of a more adequate knowledge of the inter- and intraspecific variability.

\section{REFERENCES}

Aragno, M. \& Schlegel, H. G. (1977). Alcaligenes ruhlandii (Packer \& Vishniac) comb.nov., a peritrichous hydrogen bacterium previously assigned to Pseudomonas. International Journal of Systematic Bacteriology 27, 279-281.

Ballard, R. W., Palleroni, N. J., Doudoroff, M., Stanier, R. Y. \& MANDEL, M. (1970). Taxonomy of the aerobic pseudomonads: Pseudomonas cepacia, P. marginata, $P$. alliicola and $P$. caryophylli. Journal of General Microbiology 60, 199214.

DAvIs, D. H. (1967). Studies on the Gram negative hydrogen bacteria and related organisms. Thesis, University of California, U.S.A.

Davis, D. H. Stanier, R. Y., Doudoroff, M. \& MANDEL, M. (1970). Taxonomic studies on some Gram negative polarly flagellated 'hydrogen bacteria' and related species. Archiv für Mikrobiologie 70, 1-13.

De Ley, J., Cattoir, H. \& Reynaerts, A. (1970). The quantitiative measurement of DNA hybridization from renaturation rates. European Journal of Biochemistry 12, 133-142.

DeMoss, R. D. (1955). Glucose-6-phosphate and 
6-phosphogluconic dehydrogenases from Lellconostoc mesenteroides. Methods in Enzymology 1, 328-334.

Doudoroff, M. (1940). The oxidative assimilation of sugars and related substances by Pseudomonas saccharophila with a contribution to the problem of the direct respiration of di- and polysaccharides. Enzymologia 9, 59-72.

Doudoroff, M. (1955). Disaccharide phosphorylases. Methods in Enzymology 1, 225-231.

Doudoroff, M. \& Palleroni, N. J. (1974). Genus Pseudomonas. In Bergey's Manual of Determinative Bacteriology, 8th edn, pp. 217-243. Edited by R. E. Buchanan \& N.E. Gibbons. Baltimore: Williams \& Wilkins.

Kluyver, A. J. \& Manten, A. (1942). Some observations on the metabolism of bacteria oxidizing molecular hydrogen. Antonie van Leeuwenhoek 8, 71-85.

Kodama, T., Igarashi, Y. \& Minoda, Y. (1975). Isolation and culture conditions of a bacterium grown on hydrogen and carbon dioxide. Agricultural and Biological Chemistry 39, 77-82.

LEIFSON, E. (1951). Staining, shape and arrangement of bacterial flagella. Journal of Bacteriology 62, 377-389.

MacGee, J. \& Doudoroff, M. (1954). A new phosphorylated intermediate in glucose oxidation. Journal of Biological Chemistry 210, 617-626.

Meloche, H. P. \& Wood, W. A. (1966). 6-Phosphogluconic dehydrase. Methods in Enzymology 9, 653-656.

Meloche, H. P., Ingram, J. M. \& Wood, W. A. (1966). 2-Keto-3-deoxy-6-phosphogluconic aldolase (crystalline). Methods in Enzymology 9, 520524.
Palleroni, N. J. (1956). El metabolismo de los hidratos de carbono en Pseudomonas saccharophila. Ciencia e investigación 12, 468-474.

Palleroni, N. J. (1978). The Pseudomonas Group. Shildon, Co. Durham: Meadowfield Press.

Palleroni, N. J. \& DoudorofF, M. (1956). Mannose isomerase of Pseudomonas saccharophila. Journal of Biological Chemistry 218, 535-548.

Palleroni, N. J. \& DoudorofF, M. (1971). Phenotypic characterization and deoxyribonucleic acid homologies of Pseudomonas solanacearum. Journal of Bacteriology 107, 690-696.

Palleroni, N. J. \& Doudoroff, M. (1972). Some properties and taxonomic subdivisions of the genus Pseudomonas. Annual Review of Phytopathology 10, 73-100.

Palleroni, N. J., Kunisawa, R., Contopoulou, R. \& DoudorofF, M. (1973). Nucleic acid homologies in the genus Pseudomonas. International Journal of Systematic Bacteriology 23, 333-339.

Ralston, E., Palleroni, N. J. \& Doudoroff, M. (1972). Deoxyribonucleic acid homologies of some so-called 'Hydrogenomonas' species. Journal of Bacteriology 109, 465-466.

Schatz, A. \& Boveli, C. R. (1952). Growth and hydrogenase activity of a new bacterium, Hydrogenomonas facilis. Journal of Bacteriology 63, 87-98.

Skerman, V. B. D. (1967). A Guide to the Identifcation of the Genera of Bacteria, 2nd edn, p. 253. Baltimore: Williams \& Wilkins.

Stanier, R. Y., Palleroni, N. J. \& Doudoroff, M. (1966). The aerobic pseudomonads: a taxonomic study. Journal of General Microbiology 43, 159271. 